\title{
Informing Science (IS) and Science and Technology Studies (STS): The University as Decision Center (DC) for Teaching Interdisciplinary Research
}

\author{
Teresa Castelao-Lawless \\ Grand Valley State University, USA \\ castelat@gvsu.edu
}

\author{
William F. Lawless \\ Paine College, USA \\ lawlessw@mailpaine.edu
}

\begin{abstract}
Students of history and philosophy of science courses at my University are either naïve robust realists or naïve relativists in relation to science and technology. The first group absorbs from culture stereotypical conceptions, such as the value-free character of the scientific method, that science and technology are impervious to history or ideology, and that science and religion are always at odds. The second believes science and technology were selected arbitrarily by ideologues to have privileged world views of reality to the detriment of other interpretations. These deterministic outlooks must be challenged to make students aware of the social importance of their future roles, be they as scientists and engineers or as science and technology policy decision makers. The University as Decision Center (DC) not only reproduces the social by teaching standard solutions to welldefined problems but also provides information regarding conflict resolution and the epistemological, individual, historical, social, and political mechanisms that help create new science and technology. Interdisciplinary research prepares students for roles that require science and technology literacy, but raises methodological issues in the context of the classroom as it increases uncertainty with respect to apparently self-evident beliefs about scientific and technological practices.
\end{abstract}

Keywords: STS, science, technology, practice, uncertainty, University, policy making

\section{Introduction}

My experience teaching courses in history and philosophy of science in the Arts \& Humanities and the Science \& Mathematics Divisions has been that undergraduate students start out as either naïve robust realists or naïve relativists in relation to science and technology. The first group absorbs from freshmen science courses and society at large stereotypical models of scientific and technological progress and change. Some of their conservative beliefs are the neutrality of scientific observation, that science is strictly rational, value free and a-historical, that technology is neutral in relation to politics, that science and technology are impervious to ideology, that science and religion are antagonistic forces, and that Western science emerged

Material published as part of this proceedings, either on-line or in print, is copyrighted by the author with permission granted to the publisher of Informing Science for this printing. Permission to make digital or paper copy of part or all of these works for personal or classroom use is granted without fee provided that the copies are not made or distributed for profit or commercial advantage AND that copies 1) bear this notice in full and 2) give the full citation on the first page. It is permissible to abstract these works so long as credit is given. To copy in all other cases or to republish or to post on a server or to redistribute to lists requires specific permission from the author. independently from cultures. To them, science and technology are always epistemologically privileged areas of human inquiry. Since, according to this pseudo-positivistic view, social forces are absent from the production of science and technology itself, history and sociology of science and technology are valuable only in so far as they deconstruct instances of human error or misconduct. But naïve scientific realism coupled with everyday use of technological artifacts does not parallel knowledge of scientific and technological practices themselves or reflect understanding of their historical, philosophical, and sociological underpinnings.

A second group includes students who, coming from the arts and the humanities, not only are, just as the first, awed by the thought processes, technical methodologies, and work ethic involved in the practice of science and technology but are naïve relativists in relation to their epistemological warrant. Informed by the post-modernist vision predominant in literary criticism courses, as well as in courses in anthropology, feminism and other standpoint epistemologies, and by the proliferation of cultural studies, they assume that science and technology are instruments of oppression. To them, their emergence in the West was arbi- 


\section{University as Decision Center}

trarily brought about by those who set out to destroy other epistemologically legitimate views of reality. These two groups are almost college-level analogs to C.P. Snow's "two cultures" dichotomy. But they both share a characteristic blindness toward the importance of conflict and competition in the production of new science and technology and, therefore, a deterministic and skeptic outlook regarding public policy.

Thinking that not much can be done to change the direction of science and technology by actively participating in their development or social outcomes is evidenced by students' acceptance of the inevitability of scientific and technological processes. These are reflected in the disciplinary boundaries found in college, the internalism inherent to freshmen science and technology courses, and the institutional gap between experts and nonexperts. As sociologist of science Sal Restivo said in a different context, science and technology are taken as "givens" rather than as "problems".

The University has the role of Decision Center (DC) for diffusion and producer of information not only in respect to agreed upon standards of science and technology legitimacy, but also on the historical, epistemological, social, and political mechanisms involved in their production (Lawless \& Castelao, in press). We argue that a transformation of vision can be achieved in science and technology studies (STS) courses. Only interdisciplinary research offers a diversity of angles from which undergraduate students approach scientific and technological practices. Here the focus is primarily on history and philosophy of science. Lectures, class readings, research projects, and background bibliography, however, include parts of other fields in STS such as sociology of science, science policy, and philosophy and sociology of technology.

\section{History}

From its inception in Europe during the Middle Ages until the present, Universities have been at one time mirrors and producers of perceptions of science and technology as much as initiators of social change. The role of the University has always been that of organizing and re-packing information, assimilating new into old, from consensus after tension, and of response to political and social needs. Examples from the history of science are the assimilation of Aristotelian physics into Christian cosmology, the shift from Ptolemaic to Copernican astronomy, calendar reform, and the introduction of scientific technology (meridians, telescope, microscope, etc.). Semi-standardization and dissemination of scientific information allowed by the print- ing press, the emergence of the professional scientist, as well as the connection between mechanical conceptions of nature, religion, and state power also come to mind.

Until recently universities (as well as the scientific Academies from the seventeenth century on) were reserved for the aristocrats, the clergy, and other intellectual elite. They could thrive, produce scientific revolutions, and redefine the links between science and society while inflation, disease, hunger, and war ran rampant and hit the illiterate populace the hardest. Presently, almost everybody in the United States and other countries has access to higher education. Research (be it pure or applied) is expected to accrue rapid social benefits for the majority which, in addition, is entitled to participate in the political process involved in scientific and technological choices. At this time in their history, Universities must continue to prepare young people to replicate the social and epistemological order by teaching how to solve well-defined scientific and technological problems but also to give tools to resolve illdefined problems such as unintended consequences of technological systems which can no longer be rejected (like nuclear energy) and scientific uncertainty. Ability to assess risks in science and technology and solve problems whose solution has not been already predetermined by the collective includes making visible the role of tension and agreement in the development of science and technology. Since it is at the level of the solution of ill-defined problems that the social, political, and non-epistemic nature of science and technology comes through, it is precisely here that one can better access the historical and philosophical roots of scientific and technological legitimization.

Even though many will not become scientists or engineers, all students ought to believe from what they learn in STS courses that they can have an invaluable input in social issues connected to scientific and technological development. This expectation can only be fulfilled once a realistic understanding of the mechanisms behind technological systems (be they engineering or political) as well as the plurality of cognitive and non-cognitive, personal and nonpersonal, epistemic and non-epistemic goals of science are achieved. Another goal of the university is to inform students about the contributions of culture to the construction of universally accepted standards of scientific and technological knowledge and, therefore, their objectivity despite historical and social embededness.

\section{Informing Methodologies}

Understandably, the above aims are difficult to pursue in undergraduate courses in science and technology. There it 


\section{T.Castelao-Lawless \& W.F. Lawless}

is expected that students assimilate more or less uncritically those basic principles that inform each area of inquiry. In these courses the university acculturates its students with processes stylized and edited to address the technical languages and the standards of accepted solutions that reflect its disciplines. Yet, large areas of uncertainty abound whose analysis is, as a rule, only tackled in graduate school.

Informing methodologies to be followed in history and philosophy of science courses need to take into account stereotypical images of science and technology mentioned earlier as they are the ones which students, be they naïve realists or naïve relativists, take for granted. True, informing science's purpose is to reduce clients' uncertainty to produce maximization of outcomes. But, since students' naïve perceptions of science and technology are taken by them as true, the first step is to assign reading materials and projects which increase uncertainty in relation to these apparently self-evident beliefs.

Examples used in history of science courses for the specific purpose of producing uncertainty in the naïve robust realists are:

Fleck's Genesis and Development of a Scientific Fact (on the historical development of the concept of syphilis according to disease theory, medical advancements, and social pressures); Shapin's Scientific Revolution (shows that traditional demarcations between science and society are misleading; and that the seventeenth century revolution did not reach consensus over the mechanization of nature, the role of mathematics, or the legitimacy of technology in reproducing "reality"); Winner's The Whale and the Reactor (demonstrates that artifacts can embody political agendas and their designs are flexible until "closed" by social consensus); MacKenzie and Wajcman's The Social Shaping of Technology (offers an overview of historical and philosophical positions in relation to technology, including technological determinism, social constructivism, and the political nature of urban and household technologies). Works such as these provide excellent case studies for an externalist history of the social-technology-science network model. They show ambiguities and tensions occurring before consensus (or justified true beliefs) becomes formalized in artifacts and scientific narratives.

Other works further emphasize the artificial nature of the demarcation science/society and science/non-science. For instance, Kuhn's Structure of Scientific Revolutions (shows that science is contextually adaptive; that world views build metaphysical, instrumental, theoretical, methodological commitments, and expectations which determine in large measure what scientists see and what they look for); Feyerabend's Farewell to Reason (on the pseudo-esoteric nature of science and the importance of treating science and alternative explanations of reality symmetrically); and Crosby's The Measure of Reality (argues that quantification so characteristic of seventeenth century science emerged centuries earlier in religion, painting, music, and commerce; also that the quantified, mechanical world-view depended on a gradual shift in conceptions of time and space).

More sophisticated history of science books produce uncertainty in the apparently self-evident belief that science and religion have always been antagonistic social forces. Analyses offered in Lindberg and Numbers' God and Nature show that tensions and agreements between science and religion from Plato to Einstein contributed to their mutual growth. For example, many seventeenth century scientists were people of the Church who fulfilled religious agendas while defending mechanical conceptions of nature and contributing to the rational advancement of scientific inquiry. On the other hand, Lindberg and Westman's Reappraisals of the Scientific Revolution is effective in showing the shifting social role of the engineer, the physicist, and the physician as well as the introduction of mathematics and engineering in European universities' curricula.

Literature in philosophy of science courses also challenges traditional beliefs about the epistemological and social mechanisms behind science production. Its purpose is, again, to look at science as a problem rather than a given. Examples are Bloor's Knowledge and Social Imagery (represents the "Strong Programme" in the sociology of science; shows that mathematics has a history of incompatible epistemological meanings); again Kuhn's Structure of Scientific Revolutions (helps understand, with examples from history, the underdetermination of theories by observation; addresses the conversion techniques involved in consensus from conflict over choice of scientific theories incommensurable with prevalent metaphysical beliefs); Kitcher's The Advancement of Science (analyzes the non-epistemic, personal, non-cognitive goals of science, the characteristics of human cognitive processes of assimilation and retrieval of information, the divergence and convergence of individual perceptions according to learning styles, previous schemata and past scientific practices; illustrates these with case studies on the resolution of scientific controversies); and Polanyi's Personal Knowledge (addresses the tacit, non-rational or 


\section{University as Decision Center}

(addresses the tacit, non-rational or non-verbally communicable nature of scientific and technical skills).

Two other books which challenge students' naïve conceptions of science and the scientific methodologies are Putnam's Reason, Truth and History (offers a pragmatist view on the value/fact dichotomy; argues that traditional conceptions of objectivity and privileged meta-languages are to be redefined if not completely rejected) and Feyerabend's Against Method (shows there is no one standard scientific method which all scientists follow sheepishly; also, that intuition, creation, innovation, absence of rules, anti-dogmatism and anti-authoritarianism are fundamental in scientific progress). For the role of instrumentation in scientific realism, Hacking's Representing and Intervening (demonstrates the shift from a traditional conception of scientific realism to one which includes an instrumental ontology for scientific entities); Idhe's Instrumental Realism (engages in phenomenology of technology, including human/machine interface, and AI); and Galison's How Experiments End (shows that theories are embodied in scientific technology) are good sources.

\section{Consequences}

Informing methodologies of the type suggested above are not unproblematic. In fact, one usually has to contend with consequences of deconstructing the social myth of scientific-technological rationality as well as the academic myth of radical constructivism. The first is that students who were robust naïve realists assume that relativism, arbitrariness, and irrationality in knowledge follow from the historical and social nature of science. In their turn, the group of the naïve relativists will see it as confirmation of conspiracy theories about Western scientific and technological hegemony. The second effect is that all will have difficulty understanding the relevance of historical case studies to present social circumstances. Therefore, the possibility of their future participation in the science and technology policy process is still not visible to them.

The first consequence can be addressed with projects geared toward analysis of resolutions of scientific controversies from case studies taken from journals such as $\mathrm{Sci}$ encE, Nature, Scientific American, and National Geographic. They show the political character of scientific and technological decision making, scientific uncertainty and risk assessment in both the "hard" and the "soft" sciences, the bureaucratic nature of scientific institutions, national styles of doing science, and the grant and peer review systems both in academia and in research institutes. Chubin and Chu's Science Off the Pedestal and Goldfarb's Taking
Sides also addresses uncertainty and risk management in contemporary scientific and technological problems. These sources illustrate scientific and technological conflicts, how they are resolved, how they become black-boxed from consensus by the scientific community, and how the public interferes at the level of research directions and social outcomes. They do not, however, detract from the demand that scientific inquiry be based on empirical and rational assertibility or from cooperation.

That science ought to be epistemologically on a par with less prevailing interpretations of reality can also be counteracted by showing the adverse effects of the presumption of relativism/arbitrariness in science in readings such as Gross and Levitt's Higher Superstition; Taubes' Bad Science; Masters' Beyond Relativism; Gross's The Rhetoric of Science, Levitt's Prometheus Bedeviled; and Shermer's Why People Believe Weird Things.

The second consequence, that history and philosophy of science are not relevant to understanding current scientific and technological controversies, can be resolved with comparative studies between past and present science and technology practices. Journals which engage students in such research projects are, for instance, Perspectives on Science: Historical, Philosophical, Social; Isis: An International Review devoted to the History of Science and its Cultural Influences; Technology and Culture: The International Quarterly of the Society for the History of Technology; and Science, Technology, and Human Values.

Background knowledge specifically addressing the connections between science, technology, and policy can include Hard and Jamison's The Intellectual Appropriation of Technology; Dickson's The Politics of Science; Averch's A Strategic Analysis of Science and Technology Policy; and Barke's Science, Technology, and Public Policy.

\section{Conclusion}

We need to engage undergraduate students in interdisciplinary research. Informing methodologies in STS courses will give them the ability to recognize the role of conflict in the solution of ill-defined problems in science and technology and how they have become black-boxed in formal science and technology courses. Cooperation in science and technology (which is learned in undergraduate courses) and competition (which becomes visible in history of science and other STS courses) are incommensurable processes that do not combine under normal circum- 


\section{T.Castelao-Lawless \& W.F. Lawless}

stances. One way to combine them is through the development of social structures that manage both together.

STS courses help students recognize that both naïve realism or naïve relativism in science and technology are erroneous models which cannot be used successfully either in their future roles as scientists and engineers or in public policy. They include informing methodologies that (1) increase uncertainty in regard to apparently self-evident beliefs about scientific and technological epistemologies and practices and (2) convey historical, network models of scientific and technological change. Finally, they emphasize conflict as complementary to cooperation while avoiding uninformed realism, relativism, and scientific and technological determinism in relation to public policy.

\section{References}

Anderson, Mikael Skou; Liefferink, Duncan (1997)(eds.) European Environmental Policies: The Pioneers. New York: Manchester University Press.

Averch, H.A. (1985). A Strategic Analysis of Science \& Technology Policy. Baltimore: The John's Hopkins University Press.

Barke, Richard (1986). Science, Technology, and Public Policy. Washington: CQ Press

Ben-David (1984 [1971]). The Scientist's Role in Society: A Comparative Study. Chicago: The University of Chicago Press.

Bloor, David (1991 [1976]). Knowledge and Social Imagery. Chicago: The University of Chicago Press.

Bruce, Robert V. (1987). The Launching of Modern American Science, 1846-1876. New York: Cornell University Press.

Carson, Rachel (1994 [1962]). Silent Spring. Boston: Houghton Mifflin Company.

Christianson, John R. (1999). On Tycho's Island: Tycho Brahe and his Assistants, 1570-1601. Cambridge: Cambridge University Press.

Churchland, P. \& Hooker, Clifford A. (1985). Images of Science: Essays on Realism and Empiricism with a Reply by Bas van Fraassen. Chicago: The University of Chicago Press.

Cohen, H. F. (1994). The Scientific Revolution: A Historiographical Inquiry. Chicago: The University of Chicago Press.

Crosby, A. (1997). The Measure of Reality: Quantification and Western Society, 1250-1600. Cambridge: Cambridge University Press.

Chaisson, Eric J. (1990). The Hubble Wars: Astrophysics Meets Astropolitics in the Two-Billion Dollar Struggle Over the Hubble Space Telescope. New York: Harper Perennial.
Chubin, Daryl \& Chu, Ellen (eds.)(1989). Science off the Pedestal: Social Perspectives on Science and Technology. California: Wadsworth Publishing Company.

Dickson, David (1988). The New Politics of Science. Chicago: The University of Chicago Press.

Duncan, David E. (1998). Calendar: Humanity's Epic Struggle to Determine a True and Accurate Year. New York: Avon Books.

Ellul, Jacques (1967 [1964]). The Technological Society. New York: Vintage Books.

Elster, J. (1983). Explaining Technical Change: Studies in Rationality and Social Change. New York: Cambridge University Press.

Ezrahi, Y.; Mendelsohn, E. \& Segal, H.P. (eds.)(1994). Technology, Pessimism, and Postmodernism. Massachusetts: Kluwer.

Feyerabend, P. (1988). Against Method. New York: Verso.

Feyerabend, P. (1987). Farewell to Reason. New York: Verso.

Fischer, D.H. (1996). The Great Wave: Price Revolutions and the Rhythm of History. Oxford: Oxford University Press.

Fleck, L. (1979). Genesis and Development of a Scientific Fact. Chicago: The University of Chicago Press.

Galison, Peter (1987). How Experiments End. Chicago: The University of Chicago Press.

Giere, R. (1999). Science Without Laws. Chicago: The University of Chicago Press.

Goldfarb, Theodore D. (1999)(ed.).Taking Sides: Clashing Views on Controversial Environmental Issues. Connecticut: McGraw Hill.

Gross, A. (1990). The Rhetoric of Science. Cambridge: Harvard University Press.

Gross, P.R. \& Levitt, N. (eds.)(1994). Higher Superstition: The Academic Left and its Quarrels with Science. Baltimore: The Johns Hopkins University Press.

Hacking, I. (1981). Scientific Revolutions. Oxford: Oxford University Press.

Hacking, I. (1983). Representing and Intervening: Introductory Topics in the Philosophy of Natural Science. Cambridge: Cambridge University Press.

Haraway, Donna J. (1991). Simians, Cyborgs, and Women: The Reinvention of Nature. New York: Routledge.

Hard, Mikael \& Jamison, A. (eds.) (1998). The Intellectual Appropriation of Technology: Discourses on Modernity, 1900-1939. Cambridge: MIT Press. 


\section{University as Decision Center}

Heilbron, J.L. (1999). The Sun in the Church: Cathedrals as Solar Observatories. Cambridge, Massachusetts: Harvard University Press.

Hempel, C.G. (1965). Aspects of Scientific Explanation and Other Essays in the Philosophy of Science. New York: The Free Press.

Idhe, D. (1991). Instrumental Realism: The Interface between Philosophy of Science and Philosophy of Technology. Bloomington, Indiana: Indiana University Press.

Jardine, Lisa (1999). Ingenious Pursuits: Building the Scientific Revolution. New York: Doubleday.

Johns, A. (1998). The Nature of the Book: Print and Knowledge in the Making. Chicago: University of Chicago Press.

Judson, Horace Freeland (1979). The Eight Day of Creation: The Makers of the Revolution in Biology. New York: Simon and Schuster.

Keller, Evelyn Fox (1985). Reflections on Gender and Science. New Haven: Yale University Press.

Kevles, Daniel J. (1987). The Physicists: The History of a Scientific Community in Modern America. Cambridge: Harvard University Press.

Kitcher, Philip (1993). The Advancement of Science: Science without Legend, Objectivity without Illusions. New York: Oxford University Press.

Kohlstedt, Sally G.; Rossiter, Margaret (1985)(eds.). Historical Writings on American Science: Perspectives and Prospects. Baltimore: The Johns Hopkins University Press.

Kuhn, T. (1970) The Structure of Scientific Revolutions. Chicago: The University of Chicago Press.

Latour, Bruno (1987). Science in Action: How to Follow Scientists and Engineers Through Society. Cambridge: Harvard University Press.

Latour, B. \& Woolgar, S. (1986 [1979]). Laboratory Life: The Construction of Scientific Facts. Princeton: Princeton University Press.

Lawless, W.F. \& Castelao, T. (in press, June 2001), The university between technology and society: Bridge or Decision Center? Technology and Society, special issue.

Levitt, Norman (1999). Prometheus Bedeviled: Science and the Contradictions of Contemporary Culture. New Brunswick: Rutgers University Press.

Lindberg, D. \& Numbers, R.L. (1986). God and Nature: Historical Essays on the Encounter between Christianity and Science. Berkeley: University of California Press.

Lindberg, D. \& Westman, R. (eds) (1990). Reappraisals of the Scientific Revolution. Cambridge: Cambridge University Press.

Lindberg, D. (1992). The Beginnings of Western Science: The European Scientific Tradition in Philosophical, Religious, and Institutional
Context, 600 B.C. to A.D. 1450. Chicago: The University of Chicago Press.

MacKenzie, D. \& Wajcman, C. (eds.)(1985). The Social Shaping of Technology: How the Refrigerator Got its Hum. Philadelphia: Open University Press.

Masters, R. (1993). Beyond Relativism: Science and Human Values. Hanover: University Press of New England.

Mitcham, Carl (1994). Thinking Through Technology: The Path between Engineering and Philosophy. Chicago: The University of Chicago Press.

Nelkin, Dorothy \& Lindee, M. Susan (1995). The DNA Mystique: The Gene as a Cultural Icon. New York: W. H. Freeman and Company.

Pickering, Andrew (ed.)(1992). Science as Practice and Culture. Chicago: University Chicago Press.

Polanyi, Michael (1962 [1958]). Personal Knowledge: Towards a PostCritical Philosophy. London: The University of Chicago Press.

Putnam, H.(1981). Reason, Truth, and History. New York: Cambridge University Press.

Pyenson, L. \& Sheets-Pyenson L. (1999). Servants of Nature: A History of Scientific Institutions, Enterprises, and Sensibilities. New York: W. W. Norton and Company.

Segestrale, Ullica (ed.)(2000). Beyond the Science Wars: The Missing Discourse about Science and Society. New York: State University of New York Press.

Shapin, Steven (1996). The Scientific Revolution. Chicago: The University of Chicago Press.

Shermer, Michael (1997). Why People Believe Weird Things: Pseudoscience, Superstition, and Other Confusions of Our Time. New York: W. H. Freeman and Company.

Simon, Herbert (1996). The Sciences of the Artificial. Cambridge: The MIT Press.

Sobel, Dava (1999). Galileo's Daughter: A Historical Memoir of Science, Faith, and Love. New York: Walker \& Company.

Snow, C.P. (1992 [1969]). The Two Cultures. Cambridge: Cambridge University Press.

Stanley, Autumn (1995). Mothers and Daughters of Invention: Notes for a Revised History of Technology. New Brunswick: Rutgers University Press.

Stross, Randall E. (1989). Technology and Society in Twentieth Century America. Chicago: Dorsey Press.

Thagard, Paul (1992). Conceptual Revolutions. Princeton: Princeton University Press. 
Taubes, G. (1993). Bad Science: The Short Life and the Weird Times of Cold Fusion. New York: Random House.

Vincenti, Walter (1990). What Engineers Know and How They Know It: Analytical Studies from Aeronautical History. Baltimore: The Johns Hopkins University Press.

White, Michael (1987). Isaac Newton: The Last Sorcerer. Massachusetts: Perseus Books.

Winner, Langdon (1986). The Whale and the Reactor: A Search for Limits in an Age of High Technology. Chicago: The University of Chicago Press.

Wolpert, Lewis (1993). The Unnatural Nature of Science. Cambridge: Harvard University Press.

World Commission on Environment and Development (1987). Our Common Future. Oxford University Press.

Yates, Francis A. (1964) Giordano and the Hermetic Tradition. Chicago: The University of Chicago Press.

\section{Biographies}

Teresa Castelao-Lawless is Associate Professor of Philosophy at Grand Valley State University, Michigan, where she teaches courses in history of science, philosophy of science, epistemology, science and religion, and ethics. Her publications, both in the USA and France, include French epistemology and STS.

William F. Lawless is Professor of Mathematics and Social Psychology at Paine College, Georgia, where he teaches physics with calculus, mathematics and psychology. He has authored numerous papers on group dynamics, human/machine interface, computation, and nuclear wastes clean-up. 